\title{
Correction to: Multiresistant Neisseria gonorrhoeae: a new threat in second decade of the XXI century
}

\author{
Beata Młynarczyk-Bonikowska ${ }^{1} \cdot$ Anna Majewska $^{2}$ - $\cdot$ Magdalena Malejczyk ${ }^{1} \cdot$ Grażyna Młynarczyk $^{2}$. \\ Sławomir Majewski ${ }^{3}$
}

Published online: 7 May 2020

○) Springer-Verlag GmbH Germany, part of Springer Nature 2020

\section{Correction to: Medical Microbiology and Immunology https://doi.org/10.1007/s00430-019-00651-4}

The article "Multiresistant Neisseria gonorrhoeae: a new threat in second decade of the XXI century", written by Beata Młynarczyk-Bonikowska, Anna Majewska, Magdalena Malejczyk, Grażyna Młynarczyk, Sławomir Majewski was originally published electronically on the publisher's internet portal (currently SpringerLink) on December 04, 2019 without open access.

The article has now been made Open Access. The copyright of the article changed to (c) The Author(s) 2020 and this article is licensed under a Creative Commons Attribution 4.0 International License, which permits use, sharing, adaptation, distribution and reproduction in any medium or format, as long as you give appropriate credit to the original author(s) and the source, provide a link to the Creative Commons licence, and indicate if changes were made. The images or other third party material in this article are included in the article's Creative Commons licence, unless indicated otherwise in a credit line to the material. If material is not included in the article's Creative Commons licence and your intended use is not permitted by statutory regulation or exceeds the permitted use, you will need to obtain permission directly from the copyright holder. To view a copy of this licence, visit https://creativecommons .org/licenses/by/4.0/.

The original article has been corrected.

Publisher's Note Springer Nature remains neutral with regard to jurisdictional claims in published maps and institutional affiliations.
The original article can be found online at https://doi.org/10.1007/ s00430-019-00651-4.

\section{Anna Majewska}

anna.majewska@wum.edu.pl

1 Department of Diagnostics of Sexually Transmitted Diseases, Medical University of Warsaw, 82a Koszykowa Str, 02-008 Warsaw, Poland

2 Department of Medical Microbiology, Medical University of Warsaw, 5 Chalubinskiego Str, 02-004 Warsaw, Poland

3 Department of Dermatology and Venereology, Medical University of Warsaw, 82a Koszykowa Str, 02-008 Warsaw, Poland 